\title{
Antibiotic Resistant Bacteria in the Gut of Hatchery-reared Tilapia and Coho Salmon
}

\author{
HasinaKarki, Ahmed Mustafa ${ }^{*}$, ArlisLaMaster, Shree Dhawale \\ Department of Biology, Indiana University Purdue University Fort Wayne,2101 East Coliseum Blvd, Fort Wayne, IN 46805 \\ *Corresponding Author: mustafaa@ipfw.edu
}

Copyright (c) 2013 Horizon Research Publishing All rights reserved.

\begin{abstract}
Experiments were conducted to investigate the presence of antibiotic resistant bacteria in hatchery-reared fish that are important in commercial aquaculture. Two fish species, tilapia (Oreochromisniloticus) and cohosalmon(Oncorhynchuskisu tch)were obtained from certified hatcheries to investigate ifantibiotic resistant bacteria are present in their guts. The antibiotic resistant bacteria were isolated on the basis of their resistance to ampicillin. Six out of 8 tilapia and 3 out of 8 salmon yielded antibiotic resistant isolates. These results indicated prevalence of antibiotic resistant bacteria in guts of both fish species. Five bacterial isolates were taken from each of these nine fish that yielded ampicillin resistant bacteria (45 bacterial isolates in total) to test antibiotic sensitivity using six additional antibiotics: penicillin, vancomycin, chloramphenicol, tetracycline, streptomycin, and gentamicin. In addition to ampicillin, all isolates showed resistance to penicillin and sensitivity to gentamicin.Overall, ten different resistance phenotypes were observed and many isolates displayed multidrug resistance.
\end{abstract}

Keywords Aquaculture, Bacterial Antibiotic Resistance, Coho Salmon, Tilapia

\section{Introduction}

Aquaculture is the fastest growing industry in the world that produces millions of tons of proteins and employs thousands of people. With the fast growth, this industry is facing a lot of trouble such as stress and diseases. In the recent past, aquaculture industries used antibiotics for disease control but with advancement and growth of this industry and threat of antibiotic resistant bacteria, vaccination against common fish diseases hasbecome a more common practice [1]. But because of the development of antibiotic resistance, use of antibioticsin the aquaculture industry has declined. Yet, there is no guarantee that reduction in the use of antibiotics would avoid the occurrence of antibiotic resistant bacteria in the aquatic environment. Husevag et al.[2] examined fish pathogens and their antibiotic resistance in the previously used aquaculture sites which were abandoned at the time of research and found fish pathogensin the sediments with resistance to antibiotics previously used for their treatment. This raised further awareness of the use of antibiotics in fish culture.

In our study, we wanted to see if current hatchery-raised fish in the USA have antibiotic resistant bacteria in their gut. For our studywe selected two hatchery-raised common fish species, coho salmon and tilapia, to examine. The hatcheries, from which they were purchased, stated that there was no use of antibiotics while raising these fish. The objectives of this research, therefore, were to test whether antibiotic resistant bacteria are present in coho salmon and tilapia guts and 2) to determine whether these bacterial isolates are resistant to multiple antibiotics.

\section{Materials and Methods}

\subsection{Fish Sampling}

Young tilapia (Oreochromisniloticus) and coho salmon (Oncorhynchuskisutch) were obtained from certified hatcheries and reared in the laboratory at the Life Science Resource Center, Indiana University-Purdue University Fort Wayne. Tilapia were never exposed to natural water while coho salmon were reared in water from the Mishawaka River(IN, USA) before they arrived to our laboratory. These two species were maintained according to the guidelines of Purdue Animal Care and Use Committee and acclimated in the lab for two weeks. Eight fish of each species were collected and euthanized with a lethal dose of tricanemethanesulphonate (MS 222; $200 \mathrm{mg} / 1$; Sigma, MO, USA). The length of coho salmon ranged between 13.0 and $19.5 \mathrm{~cm}$ and the length of tilapia ranged between 11.9 and $17.5 \mathrm{~cm}$. Coho salmon were smolts and tilapia were young adults.

\subsection{Collection of Bacterial Samples}

Fish were dissected and 1 inch of fish gut was excised 
aseptically and cut open to obtain the contents. Gut contents were then placed in $5 \mathrm{ml}$ of sterile saline and thoroughly mixed using a vortex for about one minute. One $\mathrm{ml}$ of this mixed suspension was taken from each sample and placed in a sterile microfuge tube for further analysis. The remaining mixtures were autoclaved and discarded.

\subsection{Isolation of Ampicillin Resistant Bacteria from Gut Samples}

The microfuge tubes containing the gut suspension were centrifuged as a quick spin for a few seconds in a micro-centrifuge. Three volumes of supernatant $(5 \mu 1,50 \mu 1$, and $100 \mu \mathrm{l}$ ) were dispensed into $5 \mathrm{ml}$ Luria-Bertani (LB) medium with $50 \mu \mathrm{g} / \mathrm{ml}$ ampicillin (LB Amp medium). LB was obtained from GIBCO BRL, CA, USAand Amp was from Sigma, MO, USA. The inoculated tubes were incubated at $37^{\circ} \mathrm{C}$ for $14-16$ hours in a shaker. If the medium in a tube was turbid the sample was considered to be positive and represented the fish yielding ampicillin resistant bacterial isolates. Tubes with no turbidity were considered negative and discarded after autoclaving. Positive samples were stored at $4^{0} \mathrm{C}$ until further use. From each of these positive tubes a quadrant streak was performed on a LB Amp medium and incubated at $37^{\circ} \mathrm{C}$ for 18 hours. From each plate five isolated colonies were sub-cultured on a LB Amp medium and incubated at $37^{\circ} \mathrm{C}$ for 18 hours for further analysis. Frozen stock for each bacterial isolate was prepared by mixing $1000 \mu 1$ of sterile double-strength $(20 \mathrm{~g}$ in $100 \mathrm{ml}$ of distilled water) skimmed milk, $480 \mu \mathrm{l}$ of the organism and $320 \mu \mathrm{l}$ of sterile $50 \%$ glycerol in $2 \mathrm{ml}$ cryovials and stored at $-80^{\circ} \mathrm{C}$.

\subsection{Testing Fish Food and Water Used to Maintain Fish in the Laboratory}

Feed used for these species were checked for ampicillin resistant bacteria by taking one gram of sample in $5 \mathrm{ml}$ of sterile saline and following the same method used for the fish gut analysis which is explained earlier in this section. One hundred and fifty $\mathrm{ml}$ of water used in the system was filtered through $0.2 \mu \mathrm{m}$ Nalgene filter unit. The retentate was suspended in $1 \mathrm{ml}$ of sterile distilled water and the sample was processed in the manner similar to the gut samples.

\subsection{Gram Staining and Antibiotic Sensitivity Test}

To further characterize the bacterial isolates, Gram staining and the Kirby Bauer method for antibiotic sensitivity tests were performed as mentioned in Dhawale and LaMaster[3]. The six antibiotics (Becton, Dickinson and Company, USA) used for the antibiotic sensitivity test were: chloramphenicol $(30 \mu \mathrm{g})$, gentamicin $(10 \mu \mathrm{g})$, penicillin $\mathrm{G}$ (10 Units), streptomycin $(10 \mu \mathrm{g})$, tetracycline $(30 \mu \mathrm{g})$ and vancomycin $(30 \mu \mathrm{g})$. The representation of the antibiotics for showing the resistance phenotype is : cap (chloramphenicol), van (vancomycin), tet (tetracycline), str (streptomycin), pen (penicillin), and gen (gentamicin)The isolates were designated as resistant (r), sensitive (s) and intermediate (i) based on the measurement of the zone of inhibition and corresponding interpretation in the chart of Clinical and Laboratory Standards Institute [4].

\section{Results}

\subsection{Ampicillin Resistant Bacterial Isolates}

From Table 1 it can be seen that the tilapia had a higher proportion of fish yielding ampicillin resistant bacteria than coho salmon. Out of the 16 fish sampled, 9 were found to have ampicillin resistant bacterial isolates. Fish feed and city water used to maintain tilapia and coho salmon in the laboratory showed total absence of antibiotic resistant bacteria.

Table1. Ampicillin resistant bacteria found in fish gut contents

\begin{tabular}{|c|c|c|}
\hline & Coho Salmon & Tilapia \\
\hline Sample size & 8 & $0.75(6 / 8)$ \\
\hline $\begin{array}{c}\text { Proportion of fish with ampicillin resistant } \\
\text { bacteria in gut samples }\end{array}$ & $0.38(3 / 8)$ & 30 \\
\hline Number of bacterial isolates* & 15 & 8 \\
\hline
\end{tabular}

*Five bacterial isolates were taken from the gut contents of fish yielding ampicillin resistant bacteria 


\subsection{Gram Staining and Antibiotic Sensitivity Test}

All 45 isolates obtained were Gram negative rods. Apart from ampicillin, all were resistant to penicillin and sensitive to gentamicin. Therefore, the phenotype pen ${ }^{\mathrm{r}}$ and gen ${ }^{\mathrm{s}}$ are not included in Tables 2 and 3, which present results of the antibiotic sensitivity test for the ampicillin resistant bacterial isolates obtained from coho salmon and tilapia, respectively. A total of ten different antibiotic resistance phenotypeswere observed (Table 4). Only one phenotype cap ${ }^{\mathrm{s}}, \operatorname{van}^{\mathrm{r}}, \operatorname{tet}^{\mathrm{s}}, \operatorname{str}^{\mathrm{s}}$ was observed in bacterial isolates from both tilapia and coho salmon gut samples.

Table 2. Antibiotic sensitivity tests for the ampicillin resistant bacterial isolates obtained from coho salmon (S) sampled from the fish laboratory

\begin{tabular}{|c|c|c|}
\hline Fish samples & Phenotype* & $\begin{array}{c}\text { Number of isolates demonstrating the } \\
\text { phenotype (out of 5 per fish) }\end{array}$ \\
\hline \multirow{2}{*}{$\mathrm{S}_{1}$} & $\mathrm{cap}^{\mathrm{s}}, \mathrm{van}^{\mathrm{s}}, \mathrm{tet}^{\mathrm{s}}, \mathrm{str}^{\mathrm{i}}$ & 3 \\
\cline { 2 - 3 } & $\mathrm{cap}^{\mathrm{s}}, \mathrm{van}^{\mathrm{i}}, \mathrm{tet}^{\mathrm{s}}, \mathrm{str}^{\mathrm{i}}$ & 2 \\
\hline $\mathrm{S}_{2}$ & $\mathrm{cap}^{\mathrm{s}}, \mathrm{van}^{\mathrm{i}}, \mathrm{tet}^{\mathrm{s}}, \mathrm{str}^{\mathrm{s}}$ & 5 \\
\hline $\mathrm{S}_{5}$ & $\mathrm{cap}^{\mathrm{s}}, \mathrm{van}^{\mathrm{r}}, \mathrm{tet}^{\mathrm{s}}, \mathrm{str}^{\mathrm{s}}$ & 5 \\
\hline
\end{tabular}

*cap (chloramphenicol), van (vancomycin), tet (tetracycline), str (streptomycin); r=resistant, i=intermediate, and $\mathrm{s}=$ sensitive

Table 3. Antibiotic sensitivity tests for the ampicillin resistant bacterial isolates obtained from tilapia (T) sampled from the fish laboratory

\begin{tabular}{|c|c|c|}
\hline Fish samples & Phenotype* & $\begin{array}{l}\text { Number of isolates demonstrating the phenotype (out } \\
\text { of } 5 \text { per fish) }\end{array}$ \\
\hline \multirow{3}{*}{$\mathrm{T}_{1}$} & cap $^{\mathrm{s}}, \operatorname{van}^{\mathrm{s}}$, tet $^{\mathrm{s}}$, str $^{\mathrm{r}}$ & 3 \\
\hline & cap $^{\mathrm{s}}, \operatorname{van}^{\mathrm{s}}$, tet $^{\mathrm{i}}, \mathrm{str}^{\mathrm{r}}$ & 1 \\
\hline & cap $^{\mathrm{s}}, \operatorname{van}^{\mathrm{r}}$, tet $^{\mathrm{i}}$, str $^{\mathrm{s}}$ & 1 \\
\hline \multirow{2}{*}{$\mathrm{T}_{3}$} & $\operatorname{cap}^{\mathrm{s}}, \operatorname{van}^{\mathrm{s}}, \operatorname{tet}^{\mathrm{s}}, \mathrm{str}^{\mathrm{r}}$ & 3 \\
\hline & cap $^{\mathrm{s}}$, van $^{\mathrm{s}}$, tet $^{\mathrm{i}}$, str $^{\mathrm{r}}$ & 2 \\
\hline \multirow{2}{*}{$\mathrm{T}_{4}$} & cap $^{\mathrm{s}}, \operatorname{van}^{\mathrm{s}}, \operatorname{tet}^{\mathrm{s}}, \mathrm{str}^{\mathrm{r}}$ & 2 \\
\hline & cap $^{\mathrm{s}}$, van $^{\mathrm{s}}$, tet $^{\mathrm{i}}$, str $^{\mathrm{r}}$ & 3 \\
\hline \multirow{2}{*}{$\mathrm{T}_{6}$} & $\mathrm{cap}^{\mathrm{s}}, \operatorname{van}^{\mathrm{r}}$, tet $^{\mathrm{s}}, \mathrm{str}^{\mathrm{s}}$ & 4 \\
\hline & cap $^{\mathrm{s}}, \operatorname{van}^{\mathrm{r}}$, tet $^{\mathrm{i}}, \mathrm{str}^{\mathrm{s}}$ & 1 \\
\hline \multirow{2}{*}{$\mathrm{T}_{7}$} & cap $^{\mathrm{s}}, \operatorname{van}^{\mathrm{i}}$, tet $^{\mathrm{i}}$, stri $^{\mathrm{i}}$ & 1 \\
\hline & cap $^{\mathrm{s}}$, van $^{\mathrm{i}}$, tet $^{\mathrm{i}}, \mathrm{str}^{\mathrm{s}}$ & 4 \\
\hline \multirow{2}{*}{$\mathrm{T}_{8}$} & $\mathrm{cap}^{\mathrm{s}}, \operatorname{van}^{\mathrm{r}}, \operatorname{tet}^{\mathrm{s}}, \mathrm{str}^{\mathrm{s}}$ & 1 \\
\hline & cap $^{\mathrm{s}}, \operatorname{van}^{\mathrm{r}}$, tet $^{\mathrm{r}}$, str $^{\mathrm{s}}$ & 4 \\
\hline
\end{tabular}

*cap (chloramphenicol), van (vancomycin), tet (tetracycline), $\operatorname{str}$ (streptomycin;r=resistant, i=intermediate, and s=sensitive

Table 4. Number of bacterial isolates showing different antibiotic resistance phenotypes

\begin{tabular}{|c|c|c|}
\hline Phenotype & Coho Salmon (15 isolates) & Tilapia (30 isolates) \\
\hline $\mathrm{cap}^{\mathrm{s}}$, van ${ }^{\mathrm{s}}, \mathrm{tet}^{\mathrm{s}}, \mathrm{str}^{\mathrm{i}}$ & 3 & \\
\hline cap $^{\mathrm{s}}, \operatorname{van}^{\mathrm{i}}$, tet $^{\mathrm{s}}, \operatorname{str}^{\mathrm{i}}$ & 2 & \\
\hline cap $^{\mathrm{s}}$, van $^{\mathrm{i}}$, tet $^{\mathrm{s}}, \mathrm{str}^{\mathrm{s}}$ & 5 & \\
\hline $\mathrm{cap}^{\mathrm{s}}, \operatorname{van}^{\mathrm{r}}$, tet $^{\mathrm{s}}, \mathrm{str}^{\mathrm{s}}$ & 5 & 5 \\
\hline cap $^{\mathrm{s}}, \operatorname{van}^{\mathrm{s}}$, tet $^{\mathrm{s}}, \operatorname{str}^{\mathrm{r}}$ & & 8 \\
\hline cap $^{\mathrm{s}}$, van $^{\mathrm{s}}$, tet $^{\mathrm{i}}$, str $^{\mathrm{r}}$ & & 6 \\
\hline cap $^{\mathrm{s}}, \operatorname{van}^{\mathrm{r}}$, tet $^{\mathrm{i}}, \mathrm{str}^{\mathrm{s}}$ & & 2 \\
\hline cap $^{\mathrm{s}}, \operatorname{van}^{\mathrm{i}}, \operatorname{tet}^{\mathrm{i}}, \operatorname{str}^{\mathrm{i}}$ & & 1 \\
\hline cap $^{\mathrm{s}}, \operatorname{van}^{\mathrm{i}}, \operatorname{tet}^{\mathrm{i}}, \operatorname{str}^{\mathrm{s}}$ & & 4 \\
\hline $\mathrm{cap}^{\mathrm{s}}, \operatorname{van}^{\mathrm{r}}, \operatorname{tet}^{\mathrm{r}}, \mathrm{str}^{\mathrm{s}}$ & & 4 \\
\hline
\end{tabular}

*cap (chloramphenicol), van (vancomycin), tet (tetracycline), str (streptomycin;r=resistant, i=intermediate, and s=sensitive 


\section{Discussion}

Miranda and Zemelman[5] and McPhearson et al. [6] have shown development of antibiotic resistance in microbial populations in fish when antibiotics were used in aquaculture. Because fish are exposed to microorganisms found in water directly or through their food source some of the bacterial flora inhabits the fish gut [7]. Thus examining the gut can shed light on the microbial population of the mileu. Although the microbial flora in fish intestines has been characterized $[8,9]$ in earlier studies, there is a more recent study that examined microflora in farm raised fish in Australia [10]. However, there are no studies on fish gut bacterial flora for fish raised in USA hatcheries. Given that tilapia, used in our study,are from a hatchery that markets young tilapia to fish farmers; and salmon, used in our study, are from a hatchery that releases them in natural waters; we wanted to examine fish from these sources for the presence of antibiotic resistant bacteria. In our study, 9/16 hatchery-reared fish yielded ampicillin resistant bacteria even though both hatcheries stated that they did not use antibiotics in their systems.

Since, coho salmon were exposed to natural water (Mishawaka River, IN, USA) and showed antibiotic resistant bacteria in their guts, it is likely that the water was the source of antibiotics or antibiotic resistant microflora. The tilapia were raised in the hatchery with no exposure to antibiotics or natural water,they also yielded antibiotic resistant bacteria. Therefore, we wanted to eliminate the possibility that these fish might have acquired antibiotic resistant bacteria from fish feed or water used in our laboratory. Our results showed that both the feed and the city water had no ampicillin resistant bacteria. Since, the fish in the laboratory were not treated with any type of antibiotics the source of antibiotic resistant bacteria in these sampled fish remains unknown.

Nevertheless, we wanted to further characterize all the bacterial isolates from the hatchery-raised fish and started with the Gram stain. Studies have documented that a high percentage of antibiotic resistant bacteria isolated from aquaculture water and/or fish were Gram negative microorganisms but Gram positive bacteria were also present $[10,6]$. However, all 45 isolates in our study were Gram negative rods. Hence, we expected the phenotypes to be $a m p^{r}, \operatorname{cap}^{\mathrm{s}}, \operatorname{van}^{\mathrm{r}}, \operatorname{tet}^{\mathrm{s}}, \operatorname{str}^{\mathrm{s}}, \operatorname{pen}^{\mathrm{r}}$, and gen ${ }^{\mathrm{s}}$ for all these isolates. Our results show that all the isolates wereamp ${ }^{\mathrm{r}}$, pen $^{\mathrm{r}}$, and gen ${ }^{\mathrm{s}}$. However, for the remaining antibiotics, the resistance phenotypes varied and there were 10 different phenotypic combinations (Table 4). Not all five isolates from each fish displayed identical phenotypes. The presence of these phenotypes shows that these fish have gut flora that are resistant to multiple drugs tested in this study. Particularly the resistance to streptomycin and tetracycline is of concern. The possible consequences of having resistant bacteria in aquaculture fish are that they can infect food handlers and may cause a public health problem with outbreaks of antibiotic resistance pathogens. These organisms by themselves may or may not be pathogenic but they can transfer their resistance genes to other bacteria.

Further research is recommended to find out the source of antibiotic resistance, which was found in these fish gut microbes and to identify specific genera and species of these bacteria. It will also be interesting to investigate whether the resistance genes are on the chromosomes or in the plasmids.If the genes are located on the plasmid they can be more easily transferred horizontally to other species.

\section{Acknowledgements}

We thank Bodine Fish Hatchery, IN for providing coho salmon for this research and Carla Barrett for maintaining aquatic lab at Life Science Resource Center at Indiana University Purdue University, Fort Wayne, IN.

\section{REFERENCES}

[1] D. J. Alderman, T. S. Hastings. Antibiotic use in aquaculture: development of antibiotic resistance-potential for consumer health risks, International Journal of Food Science and Technology, Vol. 33, 139-155, 1998.

[2] B. Husevag,B. T. Lunestad, P. J. Johannessen, O. Enger, O. B. Samuelsen. Simultaneous occurrence of Vibrio salmonicida and antibiotic-resistant bacteria in sediments at abandoned aquaculture sites, Journal of Fish diseases, Vol.14, 631-640, 1991.

[3] S. Dhawale, A. Lamaster. Microbiology Laboratory Manual ( $3^{\text {rd }}$ ed.), Mc-Graw Hill, Indiana, 2006.

[4] Clinical and Laboratory Standards Institute (CLSI). Disk Diffusion Supplement Tables, M100-S17 (M2), CLSI, Wayne Pa., 2007.

[5] C. D. Miranda, R. Zemelman. Antimicrobial multi-resistance in bacteria isolated from freshwater Chilean salmon farms, The Science of the Total Environment, Vol. 293, 207-218, 2002.

[6] R. M. McPhearson, A.DePaola, S. R.Zywno, M. L. Motes Jt., A. M. Guarino. Antibiotic resistance in Gram-negative bacteria from cultured catfish and aquaculture ponds, Aquaculture, Vol. 99, 203-211, 1991.

[7] G. H. Hansen, J. A. Olafsen. Bacterial interactions in early life stages of marine cold water fish. Microbial Ecology, Vol.38, No.1,1-26, 1999.

[8] M. M. Cahill. Bacterial flora of fishes: A review,Microbial Ecology, Vol.19, No.1, 21-41, 1990.

[9] E. E. Geldreich, N. A. Clarke. Bacterial pollution indicators in the intestinal tract of freshwater fish,Applied Microbiology, Vol.14, No.3, 429-437,1966.

[10] O. L. Akinbowale, H.Peng, M. D. Barton. Antimicrobial resistance in bacteria isolated from aquaculture sources in Australian Journal of Applied Microbiology, Vol.100, 1103-1113,2006. 